\title{
Y-haplogroup frequencies in the Slovak Romany population
}

\author{
Eva PetrejČíKovÁ ${ }^{1 *}$, Miroslav SotÁK ${ }^{1}$, Jarmila BERNASOVSKÁ ${ }^{1}$, Ivan BERNASOvSKÝ ${ }^{1}$, Adriana SOVIČOvÁ ${ }^{1}$, \\ Alexandra BôžIKOVÁ ${ }^{1}$, Iveta BOROŇOVÁ ${ }^{1}$, Petra ŠvíčKOVÁ ${ }^{1}$, Dana GABriKOVÁ ${ }^{1}$, Soňa MAČEKOVÁ ${ }^{1}$ \\ ${ }^{1}$ Department of Biology, Faculty of Humanities and Natural Science, University of Prešov, Prešov 08116, Slovakia
}

Received 22 April 2008, accepted 23 October 2008

\begin{abstract}
European 'gypsies', commonly referred to as Romanies, are represented by a large number of groups spread across many countries. We performed a population genetic study on 200 unrelated Romany males to reveal the genetic origin of the Slovak Romany population. On the basis of Y-chromosome haplotypes, we determined the corresponding Y-haplogroups using Whit Athey's Haplogroup Predictor. The obtained distribution of haplogroups provided strong evidence of Asian origins, especially Indian. The Indian Y-haplogroup $\mathrm{H}$ was the most prevalent and represented $40 \%$ of all the samples. The distribution of haplogroups was: E1b1b, 21\%; J2, 16.5\%; I1a, 14\%. Haplogroups R1a, R1b, I2a, and N1 were observed in small frequencies. The obtained genetic structure indicated that the endogamous Romany population has been shaped by a genetic drift and differential admixture, and correlates with the migratory history of the Romanies in Europe.
\end{abstract}

Key words: Y-chromosome, Y-haplogroups, Romany ‘gypsy’ population, eastern Slovakia, Indian origin

\section{Introduction}

The non-recombining portion of the human Y-chromosome provides anthropologists and geneticists with an extremely powerful tool for historical and demographic studies (Cavalli-Sforza et al., 1994). The number of studies about Short Tandem Repeats on the Y chromosome (Y-STR) increases greatly every year, but to evaluate their efficiency in forensic and anthropological sciences, it is necessary to investigate a large number of different populations (Turrina et al., 2006). Y-STR markers can be used for paternity testing, male kinship analysis, for evolutionary studies, and for studies of human migration (Butler, 2003).

There is also considerable interest in determining the $\mathrm{Y}$ chromosome haplogroup, a group or a family of Y-chromosomes related by descent. Determination of the Y-haplogroups by direct testing of single nucleotide polymorphisms (SNPs) can sometimes be an expensive process. Therefore, there is much interest in predicting the haplogroups from a set of Y-STR markers (Athey, 2005). We estimated frequency of the major Y-chromosome haplogroups from acquired Y-STR data by use of the web-accessible program, Whit Athey's Haplogroup Predictor, which is based on a Bayesian-allele-frequency approach. The program computed the probability that a Y-STR haplotype was in a haplogroup (Athey, 2006). Identification of Romany Y-chromosome haplogroups yields the ancestry of the paternal line of the population being studies.

\footnotetext{
* Correspondence to: Eva Petrejčíková, Department of Biology, Faculty of Humanities and Natural Science of Prešov, University of Prešov, 17 Novembra 1, 08116 Prešov, Slovakia.

E-mail: petrejci@unipo.sk

Published online 5 February 2009

in J-STAGE (www.jstage.jst.go.jp) DOI: 10.1537/ase.080422
}

\section{Population}

Approximately 350,000-380,000 Romanies live in Slovakia according to the official statistical list. The highest concentration $(54 \%)$ of the Romany population is located in eastern Slovakia (Vaňo, 2001). The Romany population of Slovakia represents a genetically isolated population with a high frequency of consanguinity and inbreeding, which is about 10-100 times higher than in the European population of the same region (Ferák et al., 1987). Several studies of various genetic markers in different Romany samples from Slovakia showed that their gene pool differs from the Slovak majority population and neighboring European populations (Nagy et al., 2006; Soták et al., 2008; Malyarchuk et al., 2008). The population differentiation analysis based on autosomal STR markers between Slovak Romanies and Europeans showed significant differences in spite of their geographical proximity (Soták et al., 2008). The Romany population is characterized by nomadism, a caste structure and its position in numerous countries as an underprivileged ethnic minority (Morar et al., 2004).

The first reference to Romany people in Slovakia is from the 14th century in the region of Spiš. The origin of the Romany population living in Slovakia has not yet been satisfactorily explained (Bernasovský and Bernasovská, 1999). Cultural anthropology, linguistics, and limited historical records from the surrounding majority population describe the 'gypsies' as a population of Indian origin, with their exodus from India dating approximately from the 5 th -10 th centuries $A D$, their arrival in Byzantium dating from the 11th or 12th centuries, and their dispersal throughout Europe documented at the end of the 15th century (Fraser, 1992; Marushiakova and Popov, 1997). 


\section{Methods}

\section{Samples}

Genomic DNA of 200 healthy and unrelated Slovak Romany males was extracted from buccal swabs using the Jet Quick DNA tissue kit according to the manufacturer's instructions (Genomed). Written informed consent was obtained from all participants.

\section{Y-typing and data analysis}

The multiplex polymerase chain reaction (PCR) reaction was performed for each DNA sample by use the of PowerPlex $^{\circledR}$ Y System according to the supplier's protocol (Promega). This kit coamplifies 12 STRs of the Y chromosome (Y-STRs), including the markers defined as the 'European minimal haplotype' (Gill et al., 2001) (DYS19, DYS385 a/b, DYS389I, DYS389II, DYS390, DYS391, DYS392, and DYS393), plus two loci (DYS438 and DYS439) added to this panel by the Scientific Working Group on DNA Analysis Methods (SWGDAM) (Lee et al., 2004) and DYS437. PCR products were detected by a MegaBACE 1000 genetic analyzer. MegaBACE Genetic Profile software was used to collect data and to analyze fragment sizes. Y-STR alleles were named according to the number of repeat units they contain according to the recommendations of the DNA Commission of the International Society for Forensic Genetics (Bär et al., 1997). The discrimination capacity was calculated as the number of the different haplotypes divided by the number of individuals. Prediction of Y-chromosome haplogroups from Y-STR values was performed using Whit Athey's Haplogroup Predictor Program, version 5, which is based on a Bayesian-allele-frequency approach (Athey, 2006). Twelve Y-STR markers were input and the Bayesian probability for each haplogroup was estimated. The Y-haplogroup nomenclature used in this paper was according to the recommendations of the Y-chromosome consortium (YCC) (2008).

\section{Results and Discussion}

The genetic analysis of 200 Romany samples showed 83 different haplotypes; 61 (30.5\%) occurred in only one copy. The most frequent haplotype 10-12-12-28-10-16-14-11-13$22-14 / 14$ was found in 22 copies. The gene diversity in the analyzed population was $0.9623 \pm 0.0057$ and the discrimination capacity was $41.5 \%$.

We predicted Y-chromosome haplogroups from Y-STR data by the use of Haplogroup Predictor program. Table 1 and Figure 1 show the distribution of Y-haplogroups in the Slovak Romany population. The observed haplotypes, predicted haplogroups of the Romany population and the Bayesian probability are reported in Table 2 . We found only eight haplogroups from the core 15 haplogroups in the studied population. Four haplogroups - namely H, E1b1b, J2, I1 a-occurred in high frequencies $(>10 \%)$ and together accounted for $\sim 90 \%$ of all Y-chromosomes. Haplogroups R1a, R1b, I2a, N1 were observed in small numbers (representing $0.5-4.5 \%$ ). The remaining haplogroups, E1b1a, I1b2a, J1, G2a, G2c, L, and $\mathrm{Q}$, were not detected in the samples studied. The Bayesian probability was greater than $60 \%$ in all of the samples.
Table 1. Distribution of Y-haplogroups in Slovak Romany population $(n=200)$

\begin{tabular}{lcc}
\hline Haplogroup & Number & Percent \\
\hline E1blb & 42 & 21 \\
H & 80 & 40.0 \\
Ila & 28 & 14 \\
I2a & 1 & 0.5 \\
J2 & 33 & 16.5 \\
N1 & 1 & 0.5 \\
R1a & 6 & 3 \\
R1b & 9 & 4.5 \\
Total & 200 & 100 \\
\hline
\end{tabular}

Haplogroups in the Romany population

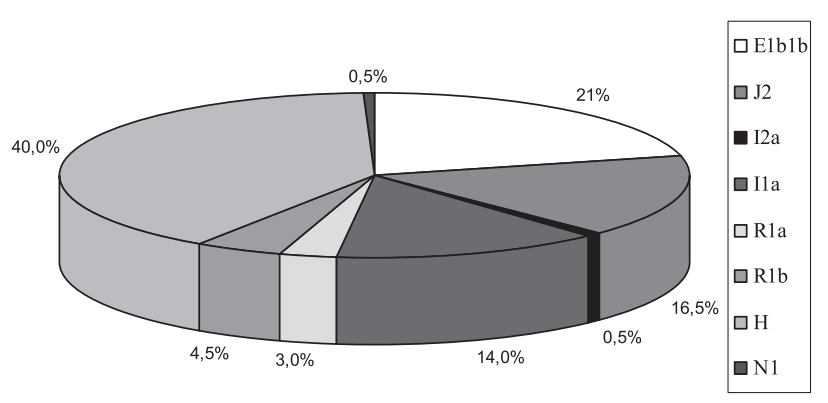

Figure 1. Graphical presentation of Y-haplogroup frequencies from Table 1.

Haplogroup $\mathrm{H}$ was found to be the most prevalent Y-lineage and represented $40 \%$ (80 individuals) of all the samples. According to the International Society of Genetic Genealogy, haplogroup $\mathrm{H}$ is typical of the Indian subcontinent area. Y-haplogroups were analyzed in three tribal populations from Andhra Pradesh in southern India and haplogroup $\mathrm{H}$ was the most prevalent with frequencies of 0.30 (Thanseem et al., 2006). Studies of Bulgarian, Macedonian, and Vlax Romanies showed that $44.8 \%, 59.6 \%$, and $73 \%$, respectively, obtained haplotypes belonging to Y-haplogroup H (Gresham et al., 2001; Kalaydjieva et al., 2001b; Pericic et al., 2005). According to these results, the Romany population in Slovakia shares a common ancestry with Romany populations from neighboring countries. Haplogroup $\mathrm{H}$ has been found very rarely in non-Romany populations and populations outside the Indian subcontinent (Wells et al., 2001). The Romany populations in Europe are the main source of haplogroup $\mathrm{H}$. The ratio of haplogroup $\mathrm{H}$ in the European populations is less than 5\% (Wells et al., 2001; Minárik et al., 2008).

Haplogroup E1b1b (formerly E3b) was the second most frequent haplogroup in the Slovak Romany population. YSTR analysis identified 16 haplotypes within this haplogroup. Haplogroup E1b1b was found in 42 Romany males (21\%) and has a distribution spread from Africa around the Mediterranean into Europe and the Middle East (Cruciani et al., 2004). In the European population, a high frequency of this haplogroup was found in Romania (21.4\%), Bulgaria (20.7\%), Albania (31.6\%), and Italy (11.5\%) (Cruciani et al., 2004). 
ZNNGRNNRN

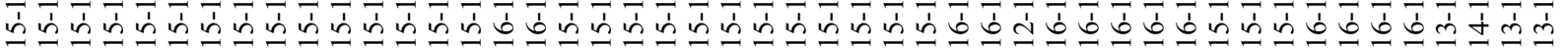

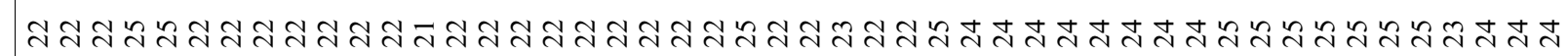

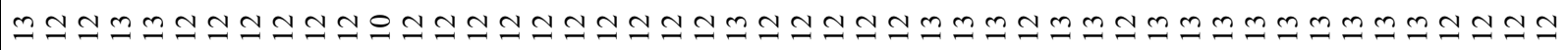

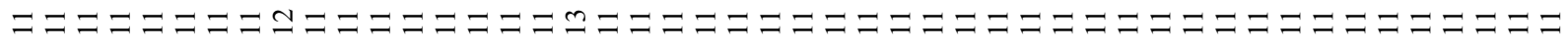

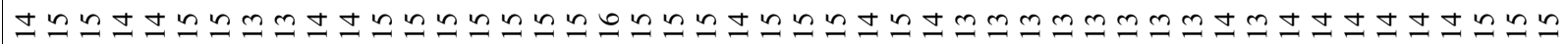

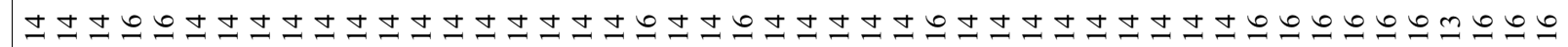

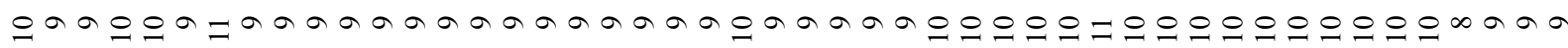

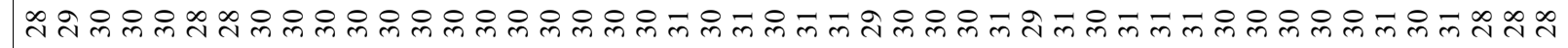

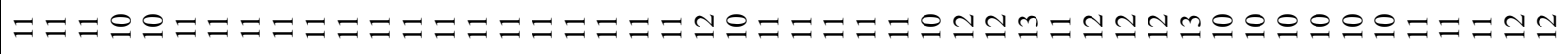

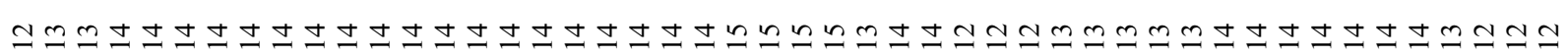
خ

으응ㅇㅇㅇㅇㅇㅇㅇㅇㅇㅇㅇㅇㅇㅇㅇㅇㅇㅇㅇㅇㅇㅇㅇㅇㅇㅇㅡ= $=0$ 으으으으으으응ㅇㅇㅇㅇㅁ으으 它 $\stackrel{\circ}{\circ}$ $\frac{\sqrt{2}}{\frac{5}{2}}$ 可 


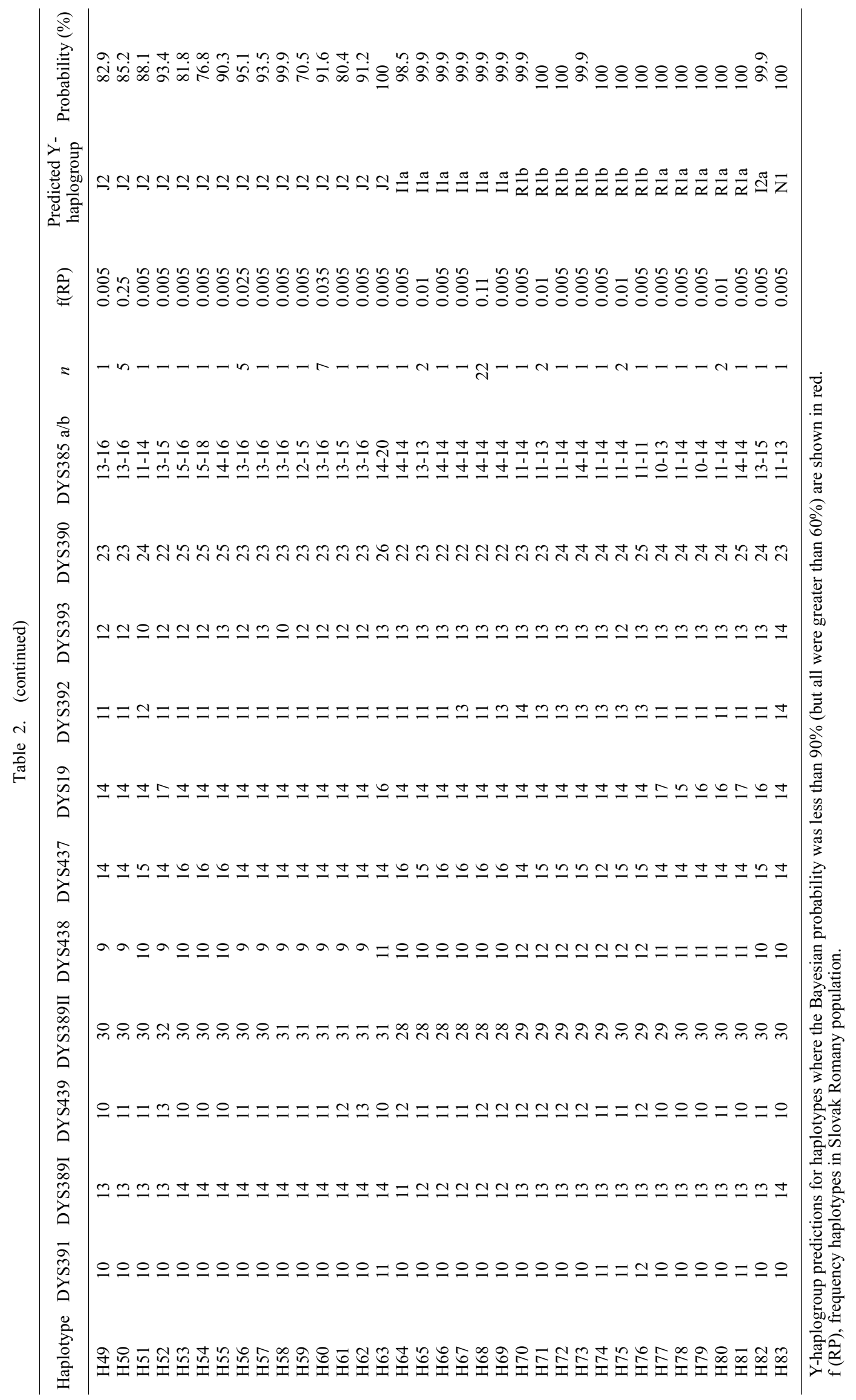


The third most frequently found haplogroup in the Slovak Romany population was $\mathrm{J} 2$ with a frequency of $16.5 \%$ (33 Romanies). Haplogroup J2 is presented in different countries such as Turkey, Iraq, Kurdistan, Lebanon, Syria, Armenia, Georgia, Italy, and many Balkan states. Both haplogroups $\mathrm{H}$ and $\mathrm{J} 2$ have been found in the south and east of India with a frequency ranging from 20 to $30 \%$ (Bamshad et al., 2001; Kivisild et al., 2003).

We observed the most frequent haplotype 10-12-12-2810-16-14-11-13-22-14/14 (DYS391, DYS389I, DYS439, DYS389II, DYS438, DYS437, DYS19, DYS392, DYS393, DYS390, DYS385a/b) within I1a haplogroup in 22 males. Haplogroup Ila was found in 28 individuals (14\%). A high frequency of haplogroup I1a has been reported in several Slavic populations (Slovaks, Czechs, Poles, Estonians, Ukrainians, Slovenes, Bosnians, and Macedonians) according to International Society of Genetic Genealogy.

The most prevalent haplogroup in Western Europe is R1b, accounting for almost 70\% of all lineages (Campbell, 2007). We found only nine individuals $(4.5 \%)$ with this haplogroup in the Romany population. The distribution of the next subclade, R1a, shows an increasing west-east frequency and variance gradients with peaks among Finno-Ugric and Slavic speakers (Pericic et al., 2005). Its frequency increases eastwards and reaches a peak in Poland (56.4\%), Hungary $(60 \%)$, and Ukraine (54\%) (Semino et al., 2000). We determined six $(3 \%)$ haplotypes in which haplogroup R1a was predicted. Semino et al. (2000) grouped together more than $95 \%$ of European Y chromosomes into 10 phylogenetically distinct haplogroups, where $70-80 \%$ of the Y-chromosome gene pool was presented by R1a, R1b, I, and N.

Research into mitochondrial DNA haplogroups presented haplogroup $\mathrm{M}$ with a high frequency in the Slovak Romany population and the Romany populations from neighbouring countries (Gresham et al., 2001; Cvjetan et al., 2004; Malyarchuk et al., 2006; Malyarchuk et al., 2008). Haplogroup $\mathrm{M}$ is rare in Europe (Richards et al., 1998; Simoni et al., 2000) and is classified as a haplogroup characteristic mainly of Asian populations (Quintana-Murci et al., 1999). Fifteen autosomal STR loci of the eastern Slovak majority population and the Romany population were described (Soták et al., 2008). This study supported the theory that the Romany population was a conglomerate of a genetically isolated founder population and the coexistence of the non-Romany and Romany populations has been influenced by a spontaneous or forced assimilation for many decades and has taken place in spite of the high level of social isolation of Romany populations.

The genetic data about the Slovak Romany population obtained in this study provide significant evidence of their Asian origins, especially Indian origins. Distributions of haplogroups can explain a migration of Romany ancestors from the Indian subcontinent through the Middle East and Balkans to Central Europe. Kalaydjieva's research has shown that the original group appeared in India some 32-40 generations ago and was small, probably under 1000 people (Kalaydjieva et al., 2001a). Consecutive population fissions have occurred after the arrival of the 'gypsies' in Europe, giving rise to numerous sub-isolates.

The achieved results indicated that the Slovak Romany population lives in socially isolated groups. It is possible to reveal their origin by following their genetic structure. The influences of the genetic drift and different degrees of admixture with non-Romany populations have shaped a peculiar mosaic of paternal lineages of the Slovak Romany population.

\section{Quality control}

The laboratory has previously participated in the Y-STR haplotype reference database (http://www.yhrd.org) quality assurance exercise in 2008 , where five quality control samples were typed correctly with the with Power-Plex Y System.

\section{Acknowledgments}

This work was supported by Grant No.: AV4/0011/07. We would like to thank all staff members who helped to collect the samples.

\section{References}

Athey T.W. (2005) Haplogroup prediction from Y-STR values using an Allele-Frequency Approach. Journal of Genetic Genealogy, 1: 1-7.

Athey T.W. (2006) Haplogroup prediction from Y-STR values using a Bayesian-Allele-Frequency Approach. Journal of Genetic Genealogy, 2: 34-39.

Bamshad M., Kivisild T., Watkins W.S., Dixon M.E., Ricker CH.E., Rao B.B., Naidu J.M., Prasad B.V.R., Reddy P.G., Rasanayagam A., Papiha S.S., Villems R., Redd A.J., Hammer M.F., Nguyen S.V., Carroll M.L., Batzer M.A., and Jorde L.B. (2001) Genetic evidence on the origins of Indian Caste Populations. Genome Research, 11: 994-1004.

Bär W., Brinkmann B., Budowle B., Carracedo A., Gill P., Lincoln P., Mayr W., and Olaisen B. (1997) DNA recommendationsfurther report of the DNA commission of the ISFH regarding the use of short tandem repeat systems. International Journal of Legal Medicine, 110: 175-176.

Bernasovský I. and Bernasovská J. (1999) Anthropology of Romanies (Gypsies). Auxological and Anthropogenetical study. NAUMA and Universitas Masarykiana, Brno.

Butler J.M. (2003) Recent developments in Y-short tandem repeat and Y-single nucleotide polymorphism analysis. Forensic Science Review, 15: 91-111.

Campbell K.D. (2007) Geographic patterns of haplogroup R1b in the British Isles. Journal of Genetic Genealogy, 3: 1-13.

Cavalli-Sforza L.L., Menozzi P., and Piazza A. (1994) The History and Geography of Human Genes. Princeton University Press, Princeton, NJ.

Cruciani F., La Fratta R., Santolamazza P., Sellitto D., Pascone R., Moral P., Watson E., Valentina G., Colomb E.B., Zaharova B., Lavinha J., Vona G., Aman R., Cali F., Akar N., Richards M., Torroni A., Novelletto A., and Scozzari R. (2004) Phylogeographic analysis of haplogroup E3b (E-M215) Y Chromosomes reveals multiple migratory events within and out of Africa. American Journal of Human Genetics, 74: 10141022 .

Cvjetan S., Tolk H.V., Barac' Lauc L., Colak I., Dordevic D., Efremovska L., Janicijevic B., Kvesic A., Martinovic K., Metspalu E., Pericic M., Parik J., Popovic D., Sijacki A., Terzic R., Villems R., and Rudan P. (2004) Frequencies of mtDNA haplogroups in southeastern Europe-Croatians, Bosnians and Herzegovinians, Serbians, Macedonians and Macedonian Romani. Collegium Anthropologicum, 28: 193198. 
Ferák V., Siváková D., and Sieglová Z. (1987) The Slovak gypsies (Romany): population with the highest coefficient of inbreeding in Europe. Bratislavské Lekárske Listy, 87: 168-175 (in Slovak).

Fraser A.M. (1992) The Gypsies. Blackwell Publishing, Oxford.

Gill P., Brenner C., Brinkmann B., Budowle B., Carracedo A., Jobling M.A., de Knijff P., Kayser M., Krawczak M., Mayr W.R., Morling N., Olaisen B., Pascali V., Prinz M., Roewer L., Schneider P.M., Sajantila A., and Tyler-Smith C. (2001) DNA commission of the International Society of Forensic Genetics: recommendations on forensic analysis using Ychromosome STRs. International Journal of Legal Medicine, 114: 305-309.

Gresham D., Morar B., Underhill P.A., Passarino G., Lin A.A., Wise Ch., Angelicheva D., Calafell F., Oefner P.J., Shen P., Tournev I., de Pablo R., Kučinskas V., Perez-Lezaun A., Marushiakova E., Popov V., and Kalaydjieva L. (2001) Origins and divergence of the Roma (gypsies). American Journal of Human Genetics, 69: 1314-133.

Kalaydjieva L., Gresham D., and Calafell F. (2001a) Genetic studies of the Roma (gypsies): a review. BMC Medical Genetics, 2: $5-18$.

Kalaydjieva L., Calafell F., Jobling M.A., Angelicheva D., de Knijff P., Rosser Z.H., Hurles M.E., Underhill P., Tournev I., Marushiakova E., and Popov V. (2001b) Patterns of inter- and intra-group genetic diversity in the Vlax Roma as revealed by $\mathrm{Y}$ chromosome and mitochondrial DNA lineages. European Journal of Human Genetics, 9: 97-104.

Kivisild T., Rootsi S., Metspalu M., Mastana S., Kaldma K., Parik J., Metspalu E., Adojaan M., Tolk H.-V., Stepanov V., Gölge M., Usanga E., Papiha S.S., Cinniogclu C., King R., Cavalli-Sforza L., Underhill P.A., and Villems R. (2003) The genetic heritage of the earliest settlers persists both in India Tribal and Caste populations. American Journal of Human Genetics, 72: 313-332.

Lee D., Sims G., Newman J., Laad C., Smerick S., Barna C., Gross A., Butler J., Prinz M., Hartmann J., Kinsey P., Figarelli D., and Ballantyne J. (2004) Report on the current activities of the Scientific Working Group on DNA Analysis Methods YSTR Subcommittee. Forensic Science Communications, 6.

Malyarchuk B.A., Grzybowski T., Derenko M.V., Czarny J., and Miscicka-Slivvka D. (2006) Mitochondrial DNA diversity in the Polish Roma. Annals of Human Genetics, 70: 195-206.

Malyarchuk B.A., Perkova M.A., Derenko M.V., Vanecek T., Lazur J., and Gomolcak P. (2008) Mitochondrial DNA variability in Slovaks, with application to the Roma origin. Annals of Human Genetics, 72(2): 228-240.

Marushiakova E. and Popov V. (1997) Gypsies (Roma) in Bulgaria. Peter Lang Publishing, Frankfurt am Main.

Minárik M., Zastera J., Sekerka P., Roewer L., Williweit S., and Benesova L. (2008) Central European genetic population data from large-scale 12 STR Y-Haplotyping in the Czech republic. Poster presented on 6th International Y Chromosome User Workshop: 'DNA in Forensics 2008', Ancona.

Morar B., Gresham D., Angelicheva D., Tournev I., Gooding R., Guergueltcheva V., Schmidt C., Abicht A., Lochmuller H., Tordai A., Kalmar L., Nagy M., Karcagi V., Jeanpierre M., Herczegfalvi A., Beeson D., Venkataraman V., Warwick Carter K., Reeve J., de Pablo R., Kucinskas V., and Kalaydjieva L. (2004) Mutation history of the Roma/gypsies. American Journal of Human Genetics, 75: 569-609.
Nagy M., Henke L., Henke J., Chatthopadhyay P.K., Völgyi A., Zalán A., Peterman O., Bernasovská J., and Pamjav H. (2006) Searching for the origin of Romanies: Slovakian Romani, Jats of Haryana and Jat Sikhs Y-STR data in comparison with different Romani populations. Forensic Science International, 169: 19-26.

Quintana-Murci L., Semino O., Bandelt H.J., Passarino G., McElreavey K., and Santachiara-Benerecetti A.S. (1999) Genetic evidence of an early exit of Homo sapiens sapiens from Africa through eastern Africa. Nature Genetics, 23: 437-441.

Richards M.B., Macaulay V.A., Bandelt H.J., and Sykes B.C. (1998) Phylogeography of mitochondrial DNA in western Europe. Annals of Human Genetics, 62: 241-260.

Pericic M., Lauc L.B., Klaric I.M., Rootsi S., Janicijevic B., Rudan I., Terzic R., Colak I., Kvesic A., Popovic D., Sijacki A., Behluli I., Thorthevic D., Efremovska L., Bajec E.D., Stefanovic B.D., Villems R., and Rudan P. (2005) Highresolution phylogenetic analysis of southeastern Europe (SEE) traces major episodes of paternal gene flow among Slavic populations. Molecular Biology and Evolution, 22: 1964-1975.

Semino O., Passarino G., Oefner P.J., Lin A.A., Arbuzova S., Beckman L.E., De Benedictis G., Francalacci P., Kouvatsi A., Limborska S., Marcikiae M., Mika A., Mika B., Primorac D., Santachiara-Benerecetti A.S., Cavalli-Sforza L.L., and Underhill P.A. (2000) The genetic legacy of Paleolithic Homo sapiens sapiens in extant Europeans: a Y chromosome perspective. Science, 290: 1155-1159.

Simoni L., Calafell F., Pettener D., Bertranpetit J., and Barbujani G. (2000) Geographic patterns of mtDNA diversity in Europe. American Journal of Human Genetics, 66: 262-278.

Soták M., Petrejčíková E., Bernasovská J., Bernasovský I., Sovičová A., Boroňová I., Švićčková P., Bôžiková A., and Gabriková D. (2008) Genetic variation of 15 autosomal STR loci in eastern Slovak Caucasian and Romany (gypsy) population. Forensic Science International, 3: 21-25.

Thanseem I., Thangaraj K., Chaubey G., Singh V.K., Bhaskar L., Reddy B.M., Reddy A.G., and Singh L. (2006) Genetic affinities among the lower castes and tribal group of India: inherence from $\mathrm{Y}$ chromosome and mitochondrial DNA. BMC Medical Genetics, 7: 42.

Turrina S., Atzei R., and Leo D.D. (2006) Haplotype analysis of the Powerplex Y System in northeast population from Italy. International Congress Series, 1288: 265-267.

Vaňo B. (2001) The demographic characteristics of Roma population in Slovakia. Institute of Informatics and Statistics, Bratislava (in Slovak).

Y-chromosome consortium (2008) New binary polymorphisms reshape and increase resolution of the human Y chromosomal haplogroup tree. Genome Research, 18: 830-838.

Wells R.S., Yuldasheva N., Ruzibakiev R., Underhill P.A., Evseeva I., Blue-Smith J., Jin L., Su B., Pitchappan R., Shanmugalakshmi S., Balakrishnan K., Read M., Pearson N.M., Zerjal T., Webster M.T., Zholoshvili I., Jamarjashvili E., Gambarov S., Nikbin B., Dostiev A., Aknazarov O., Zalloua P., Tsoy I., Kitaev M., Mirrakhimov M., Chariev A., and Bodmer W.F. (2001) The Eurasian Heartland: A continental perspective on Y-chromosome diversity. Proceedings of the National Academy of Sciences USA, 98: 10244-10249. 